\title{
ОД ТЕОРИЈЕ ЧИТАЊА ДО ПОЕТИКЕ ЧИТАЛАЦА
}

(Мирјана Бојанић Ћирковић, Читалаи у науци о књижевности - од антике до савремених теорија читана, Ниш: Филозофски факултет, 2020)

Монографија Мирјане Бојанић Ћирковић Читалаи у науиз о кюижевности - од антике до савремених теорија читаға састоји се из следећих делова: І. Концепт читаоца у књижевнотеоријској дијахронији, II. Аспекти рецепције и статус читаоца у античким поетичким списима, III. Процес читања и концепти читалаца од феноменологије до теориje рецепције, IV. Ка теоријама читања као методолошкој оријентацији, V. Критика читалачког одговора, VI. Посткласичне теорије читања, VII. Синтезе, VIII. Апликативност посткласичних концепата читалаца, IX. Регистар појмова, Х. Литература.

У поглављима која обухватају дијахронијски преглед теорија читања разматрана је сложена и динамична поетичка вертикала која се односи на питања деловања књижевности (присутних још од антике), читаочеву интеракцију са текстом као темеља процеса активног читања и (енкодирану) реакцију (одговор, одзив) на текстуалне елементе као ефекта дате интеракције. Основни истраживачки корпус у овом делу чине антички поетички списи (Платонова теорија сазнања, Аристотелова теорија катарзе, Хорацијева синтеза читања као уживања, разума и образовања и Псеудолонгинов концепт реципијента), руски формализам, нова критика, структурализам и класична наратологија, потом, феноменологија, реторичка теорија читања, теорија рецепције, критика читалачког одговора и најновије, посткласичнонаратолошке оријентације у приступу феномену читања и концепту читаоца, са посебним нагласком на когнитивне теорије урањања, нечитаоца и наративне емпатије. Посебни одељци посвећени су читаоцу насладе у теорији Ролана Барта, Изеровом концепту имплицитног читаоца, Принсовом појму наратера и Шмидовом појму нарататора. Док је осврт на феноменолошки концепт активног читаоца и новокритичарски концепт помног читања (close reading) с правом нашао место на почетку прегледа рецепционистичких теорија двадесетог века, дотле је детаљна анализа концепата читаоца у руском формализму и структурализму пружила нове увиде у нека мање 
истражена постигнућа ове две текстоцентричне оријентације у науци о књижевности (улога „продужене перцепције” у формализму, структуралистичка дистинкција наратера и нарататора). Као методолошке оријентације које се одвајају од строгог иманентизма у овом дијахронијском следу о читацу анализиране су реторичка теорија читања и концепт реторичког читаоца, као и бројне подврсте тзв. рецепционистичких теорија. Поред истицања улоге, сада већ класика естетике рецепције Х. Р. Јауса, ауторка је представила и мање познате теоретичаре читања: Карлхајнца Штирлеа и његово разликовање наивног и упућеног читаоца, као и типолошки преглед читалаца у теоријама Манфреда Наумана и Харалда Вајнриха.

Фокусирајући се на оне теоријске увиде који су утицали на конституисање теорија читања као методолошке оријентације ауторка у четвртом поглављу анализира концепте читаоца Ролана Барта (од семиотички предодређеног читаоца као кода, до читаоца задовољства и насладе из Бартове касније, постструктуралистичке фазе). Централно место у овом поглављу припада родоначелнику актуелних рецепционистичких оријентација, Волфгангу Изеру и његовом концепту имплицитног читаоца. С обзиром на то да су српској научнокњижевној јавности познати тек неколики преводи Изерових текстова о читаоцу, овај део монографије представља и прво детаљније увођење у Изерову теорију имплицитног читаоца, као и у мене и трансформације које су је пратиле кроз време. Посебно је вредан пажње полемички приступ функцији емпиријског читаоца у улози имплицитног читаоца те његовом уделу у Gestalt-y.

Пето поглавље доноси детаљну генезу критике читалачког одговора, њено територијално, терминолошко и временско одређење уз систематизацију корпуса кључних текстова. Поред контекстуализације овог хетерогеног покрета унутар поетике постмодернизма, ауторка више пажње посвеђује његовим водећим ауторима, Стенлију Фишу и Норману Холанду и њиховим концептима обавештеног читаоца, интерпретативне заједнице и трансактивног читаоца.

Усмереност ка најновијим теоријама које долазе са поља посткласичне реторичке теорије наратива и когнитивних теорија читања води до концепата наративне и ауторске публике и етичког читаоца у теорији Џејмса Фелана и Питера Рабиновича, односно, уроњеног читаоца (Жан-Мари Шефер, Мари-Лор Рајан), неприродног читаоца (Јан Албер, Стефан Иверсен) и нечитаоца (Пјер Бајар), као репрезентативних концепата когнитивнонаратолошких теорија рецепције. Апострофирани су основни начини читаочеве партиципације у наративу: нормализација, искуственост и наративизација, читање кроз конвенције. Ауторка оправдано закључује да „посткласична наратологија, односно наратоло- 
гије, нарочито њихова реторичка и когнитивна оријентација, са пуним правом могу се синонимично одредити као теорије читања“.

У последњој трећини монографије релевантност теоријских платформи о читаоцу демонстрирана је на делу Милорада Павића, једног од најинтригантнијих аутора савремене српске књижевности када је реч о фигурама читалаца. Уједно, овај апликативни део монографије потврђује смисао и методолошку ваљаност књижевнотеоријског дискурса који изван домена теоријске поетике мора рачунати на књижевноуметнички текст као свој примарни извор. Типологија читалаца у романима Милорада Павића, вићена из угла савремених теорија читања, након референтне публикације Јована Делића (Хазарска призма, 1991) доноси нов поглед на поетику овог канонског писца, неистражену у досадашњој критичкој рецепцији. Полазећи од концепције читања као креације, Умберта Ека, ауторка закључује да се „од романа Унутрашња страна ветра уочава Павићево имплицитно поигравање са посткласичним стратегијама читања“. Оно је „конкретизовано кроз умножавање имплицитног аутора као ефекта читања Унутрашње стране ветра, преиспитивање поставки неприродне наратологије у Другом телу, кроз емпатијско-етички модел читања Вештачког младежа, трансактиво и интермедијално читање Униката и проблем наративне (не)кохеренције у Позоришту од хартије“. Након минуциозне анализе читалаца-ликова као фигуре читања Павићевих романа, ауторка посвећује пажњу њиховом реторичком аспекту у Павићевој позној прози сагледаној из интердисциплинарне перспективе односа између аутора, књижевног лика и читаоца. Узимајући у обзир шири контекст Павићевог стваралаштва (и његове научне, есејистичке и књижевноуметничке текстове), Мирјана Бојанић Ћирковић износи закључак о „двострукој кодираности“ манифестованој у фигурама „повлашћеног читаоца и корисника“. Павићеви теоријски радови сагледани су примарно из перспективе експлицитне поетике и доминантне опозиције између читања и коришћења, а у релацији и интеракцији са теоријама читања Умберта Ека, Итала Калвина, те са Бартовим, Калеровим и Бајаровим теоријским поставкама са којима је Павић успостављао полемички дијалог. О ширини аналитичко-синтетичког приступа Павићевом делу говори Прилог који садржи попис маски читалаца у романима Милорада Павића (укупно 145 наведених одредница овог јединственог појмовника). С обзиром на истраживачку тему, индекс појмова и литература који се налазе на крају монографије, помоћи ће (оним стварним) читаоцима да се лакше крећу кроз књижевнонаучну терминологију и методолошке путоказе.

За разлику од истраживања у области историје читања, која у српској науци о књижевности има дугу традицију, теоријска поетика 
читаоца и читања предмет је тек малобројних публикација (издвајамо књиге Јована Попова, Горане Раичевић и Радована Вучковића). Базирана на рукопису одбрањене докторске дисертације („Типологија читалаца у романима Милорада Павића из угла савремених теорија читања“), монографија Мирјане Бојанић Ћирковић прва је обимнија студија која је у српској науци о књижевности посвећена типолошком истраживању феномена читаоца и читања унутар ауторске поетике једног писца. Квалитет научног приступа потврђен је у компаративном контексту унутар кога је ауторка укрстила различите параметре (књижевнотеоријска традиција, историја читања Павићевог дела, имплицитна и експлицитна ауторска поетика, савремени методолошки приступи), како би их критички реинтепретирала и дошла до нових синтеза и увида у стваралачку поетику једног од најчитанијих и најпревођенијих савремених српских писаца.

Снежана М. Милосављевић Милић

Универзитет у Нишу Филозофски факултет Департман за србистику snezana.milosavljevic.milic@filfak.ni.ac.rs 